\title{
Sensitivity and uncertainty in crop water footprint accounting: a case study for the Yellow River basin
}

\author{
L. Zhuo, M. M. Mekonnen, and A. Y. Hoekstra \\ Twente Water Centre, University of Twente, Enschede, the Netherlands \\ Correspondence to: L. Zhuo (1.zhuo@utwente.nl) \\ Received: 3 December 2013 - Published in Hydrol. Earth Syst. Sci. Discuss.: 7 January 2014 \\ Revised: 3 April 2014 - Accepted: 5 May 2014 - Published: 17 June 2014
}

\begin{abstract}
Water Footprint Assessment is a fast-growing field of research, but as yet little attention has been paid to the uncertainties involved. This study investigates the sensitivity of and uncertainty in crop water footprint (in $\mathrm{m}^{3} \mathrm{t}^{-1}$ ) estimates related to uncertainties in important input variables. The study focuses on the green (from rainfall) and blue (from irrigation) water footprint of producing maize, soybean, rice, and wheat at the scale of the Yellow River basin in the period 1996-2005. A grid-based daily water balance model at a 5 by 5 arcmin resolution was applied to compute green and blue water footprints of the four crops in the Yellow River basin in the period considered. The one-at-a-time method was carried out to analyse the sensitivity of the crop water footprint to fractional changes of seven individual input variables and parameters: precipitation $(\mathrm{PR})$, reference evapotranspiration $\left(\mathrm{ET}_{0}\right)$, crop coefficient $\left(K_{\mathrm{c}}\right)$, crop calendar (planting date with constant growing degree days), soil water content at field capacity $\left(S_{\max }\right)$, yield response factor $\left(K_{\mathrm{y}}\right)$ and $\max -$ imum yield $\left(Y_{\mathrm{m}}\right)$. Uncertainties in crop water footprint estimates related to uncertainties in four key input variables: PR, $\mathrm{ET}_{0}, K_{\mathrm{c}}$, and crop calendar were quantified through Monte Carlo simulations.

The results show that the sensitivities and uncertainties differ across crop types. In general, the water footprint of crops is most sensitive to $\mathrm{ET}_{0}$ and $K_{\mathrm{c}}$, followed by the crop calendar. Blue water footprints were more sensitive to input variability than green water footprints. The smaller the annual blue water footprint is, the higher its sensitivity to changes in PR, $\mathrm{ET}_{0}$, and $K_{\mathrm{c}}$. The uncertainties in the total water footprint of a crop due to combined uncertainties in climatic inputs (PR and $\mathrm{ET}_{0}$ ) were about $\pm 20 \%$ (at $95 \%$
\end{abstract}

confidence interval). The effect of uncertainties in $\mathrm{ET}_{0}$ was dominant compared to that of PR. The uncertainties in the total water footprint of a crop as a result of combined key input uncertainties were on average $\pm 30 \%$ (at $95 \%$ confidence level).

\section{Introduction}

More than 2 billion people live in highly water stressed areas (Oki and Kanae, 2006), and the pressure on freshwater will inevitably be intensified by population growth, economic development and climate change in the future (Vörösmarty et al., 2000). The water footprint (Hoekstra, 2003) is increasingly recognized as a suitable indicator of human appropriation of freshwater resources and is becoming widely applied to get better understanding of the sustainability of water use. In the period 1996-2005, agriculture contributed $92 \%$ to the total water footprint of humanity (Hoekstra and Mekonnen, 2012).

Water footprints within the agricultural sector have been extensively studied, mainly focusing on the water footprint of crop production, at scales from a sub-national region (e.g. Aldaya and Llamas, 2008; Zeng et al., 2012; Sun et al., 2013), to a country level (e.g. Ma et al., 2006; Hoekstra and Chapagain, 2007b; Kampman et al., 2008; Liu and Savenije, 2008; Bulsink et al., 2010; Ge et al., 2011) to the global level (Hoekstra and Chapagain, 2007a; Liu et al., 2010; Siebert and Döll, 2010; Mekonnen and Hoekstra, 2011; Hoekstra and Mekonnen, 2012). The green or blue water footprint of a crop is normally expressed by a single volumetric number 
referring to an average value for a certain area and period. However, the water footprint of a crop is always estimated based on a large set of assumptions with respect to the modelling approach, parameter values, and data sets for input variables used, so that outcomes carry substantial uncertainties (Mekonnen and Hoekstra, 2010; Hoekstra et al., 2011).

Together with the carbon footprint and ecological footprint, the water footprint is part of the "footprint family of indicators" (Galli et al., 2012), a suite of indicators to track human pressure on the surrounding environment. Nowadays, it is not hard to find information in literature on uncertainties in the carbon footprint of food products (Röös et al., 2010, 2011) or uncertainties in the ecological footprint (Parker and Tyedmers, 2012). However, there are hardly any sensitivity or uncertainty studies available in the water footprint field (Hoekstra et al., 2011), while only some subjective approximations and local rough assessments exist (Mekonnen and Hoekstra, 2010, 2011; Hoekstra et al., 2012; Mattila et al., 2012). Bocchiola et al. (2013) assessed the sensitivity of the water footprint of maize to potential changes of certain selected weather variables in northern Italy. Guieysse et al. (2013) assessed the sensitivity of the water footprint of fresh algae cultivation to changes in methods to estimate evaporation.

In order to provide realistic information to stakeholders in water governance, analysing the sensitivity and the magnitude of uncertainties in the results of a Water Footprint Assessment in relation to assumptions and input variables would be useful (Hoekstra et al., 2011; Mekonnen and Hoekstra, 2011). Therefore, the objectives of this study are (1) to investigate the sensitivity of the water footprint of a crop to changes in input variables and parameters, and (2) to quantify the uncertainty in green, blue, and total water footprints of crops due to uncertainties in input variables at the scale of a river basin. The study focuses on the water footprint of producing maize, soybean, rice, and wheat in the Yellow River basin, China, for each separate year in the period 1996-2005. Uncertainty in this study refers to the uncertainty in water footprint that accumulates due to the uncertainties in inputs propagated through the accounting process, which is reflected in the resulting estimates (Walker et al., 2003).

\section{Study area}

The Yellow River basin (YRB), drained by the Yellow River (Huang $\mathrm{He}$ ), is the second largest river basin in China, with a drainage area of $795 \times 10^{3} \mathrm{~km}^{2}$ (YRCC, 2011). The Yellow River is $5464 \mathrm{~km}$ long, originates from the Bayangela Mountains of the Tibetan Plateau, flows through nine provinces (Qinghai, Sichuan, Gansu, Ningxia, Inner Mongolia, Shaanxi, Shanxi, Henan and Shandong), and finally drains into the Bohai Sea (YRCC, 2011). The YRB is usually divided into three reaches: the upper reach (upstream of Hekouzhen, Inner Mongolia), the middle reach (upstream of Taohuayu, Henan province) and the lower reach (draining into the Bohai Sea).

The YRB is vital for food production, natural resources and socioeconomic development of China (Cai et al., 2011). The cultivated area of the YRB accounts for $13 \%$ of the national total (CMWR, 2010). In 2000, the basin accounted for $14 \%$ of the country's crop production, with about 7 million ha of irrigated land in a total cultivated area in the basin of 13 million ha (Ringler et al., 2010). The water of the Yellow River supports 150 million people with a per capita blue water availability of $430 \mathrm{~m}^{3}$ per year (Falkenmark and Widstrand, 1992; Ringler et al., 2010). The YRB is a net virtual water exporter (Feng et al., 2012) and suffers severe water scarcity. The blue water footprint in the basin is larger than the maximum sustainable blue water footprint (runoff minus environmental flow requirements) 8 months out of the year (Hoekstra et al., 2012).

\section{Methods and data}

\subsection{Crop water footprint accounting}

For the period 1996-2005, we calculated annual green and blue water footprints (WF) related to the production of maize, soybean, rice, and wheat in the YRB. The green and blue WF per unit mass of crop $\left(\mathrm{m}^{3} \mathrm{t}^{-1}\right)$ were calculated by dividing the green and blue crop water use $\left(\mathrm{CWU}, \mathrm{m}^{3} \mathrm{ha}^{-1}\right)$ by the crop yield $\left(Y, \mathrm{tha}^{-1}\right)$, respectively (Hoekstra et al., 2011). The total WF refers to the sum of green and blue WF.

A grid-based dynamic water balance model, developed by Mekonnen and Hoekstra (2010, 2011), is used to compute different components of CWU according to the daily soil water balance. The model has a spatial resolution of 5 by 5 arcmin (about $7.4 \mathrm{~km} \times 9.3 \mathrm{~km}$ at the latitude of the YRB). The daily root zone soil water balance for growing a crop in each grid cell in the model can be expressed in terms of soil moisture $\left(S_{[t]}, \mathrm{mm}\right)$ (Mekonnen and Hoekstra, 2010):

$S_{[t]}=S_{[t-1]}+I_{[t]}+\mathrm{PR}_{[t]}+\mathrm{CR}_{[t]}-\mathrm{RO}_{[t]}-\mathrm{ET}_{[t]}-\mathrm{DP}_{[t]}$,

where $S_{[t-1]}(\mathrm{mm})$ refers to the soil water content on day $(t-1), I_{[t]}(\mathrm{mm})$ the irrigation water applied on day $\mathrm{t}, \mathrm{PR}_{[t]}$ $(\mathrm{mm})$ precipitation, $\mathrm{CR}_{[t]}(\mathrm{mm})$ the capillary rise from the groundwater, $\mathrm{RO}_{[t]}(\mathrm{mm})$ water runoff, $\mathrm{ET}_{[t]}(\mathrm{mm})$ actual evapotranspiration and $\mathrm{DP}_{[t]}(\mathrm{mm})$ deep percolation on day $t$.

$\mathrm{CWU}_{\text {green }}$ and $\mathrm{CWU}_{\text {blue }}$ over the crop-growing period (in $\mathrm{m}^{3} \mathrm{ha}^{-1}$ ) were calculated from the accumulated corresponding ET (mm day $\left.{ }^{-1}\right)$ (Hoekstra et al., 2011):

$$
\begin{aligned}
& \mathrm{CWU}_{\text {green }}=10 \times \sum_{d=1}^{\operatorname{lgp}} \mathrm{ET}_{\text {green }} \\
& \mathrm{CWU}_{\text {blue }}=10 \times \sum_{d=1}^{\operatorname{lgp}} \mathrm{ET}_{\text {blue }}
\end{aligned}
$$


Table 1. Crop characteristics for maize, soybean, rice and wheat in the Yellow River basin.

\begin{tabular}{|c|c|c|c|c|c|c|c|c|c|}
\hline & \multicolumn{3}{|c|}{ Crop coefficients } & \multirow{2}{*}{$\begin{array}{l}\text { Planting } \\
\text { date }\end{array}$} & \multirow{2}{*}{$\begin{array}{l}\text { Growing } \\
\text { period } \\
\text { (days) }\end{array}$} & \multicolumn{4}{|c|}{ Relative crop-growing stages } \\
\hline & $K_{\mathrm{c} \_ \text {ini }}$ & $K_{\mathrm{c} \_}$mid & $K_{\mathrm{c} \_ \text {end }}$ & & & $L \_$ini & $L \_\mathrm{dev}$ & $L \_$mid & $L \_$late \\
\hline Maize & 0.70 & 1.20 & 0.25 & $1 \mathrm{Apr}$ & 150 & 0.20 & 0.27 & 0.33 & 0.20 \\
\hline Soybean & 0.40 & 1.15 & 0.50 & 1 Jun & 150 & 0.13 & 0.17 & 0.50 & 0.20 \\
\hline Rice & 1.05 & 1.20 & 0.90 & 1 May & 180 & 0.17 & 0.17 & 0.44 & 0.22 \\
\hline Wheat & 0.70 & 1.15 & 0.30 & $1 \mathrm{Oct}$ & 335 & 0.48 & 0.22 & 0.22 & 0.07 \\
\hline
\end{tabular}

Sources: Allen et al. (1998); Chen et al. (1995); Chapagain and Hoekstra (2004).

The accumulation was done over the growing period from the day of planting $(d=1)$ to the day of harvest (lgp, the length of growing period in days). The factor $10\left(\mathrm{~m}^{3} \mathrm{~mm}^{-1} \mathrm{ha}^{-1}\right)$ is applied to convert the $\mathrm{mm}$ to $\mathrm{m}^{3} \mathrm{ha}^{-1}$. The daily ET $\left(\mathrm{mm} \mathrm{day}^{-1}\right)$ was computed according to Allen et al. (1998) as

$\mathrm{ET}=K_{\mathrm{S}}[t] \times K \mathrm{c}[t] \times \mathrm{ET}_{0}[t]$

where $K_{\mathrm{c}}[t]$ is the crop coefficient, $K_{\mathrm{s}}[t]$ a dimensionless transpiration-reduction factor dependent on available soil water, and $\mathrm{ET}_{0}[t]$ the reference evapotranspiration $\left(\mathrm{mm} \mathrm{day}^{-1}\right)$. The crop calendar and $K_{\mathrm{c}}$ values for each crop were assumed to be constant for the whole basin, as shown in Table $1 . K_{\mathrm{S}}[t]$ is assessed based on a daily function of the maximum and actual available soil moisture in the root zone (Allen et al., 1998):

$K_{\mathrm{S}}[t]= \begin{cases}\frac{s[t]}{(1-p) \times S_{\max }[t]} & S[t]<(1-p) \times S_{\max }[t] \\ 1 & \text { otherwise, }\end{cases}$

where $S_{\max }[t]$ is the maximum available soil water in the root zone ( $\mathrm{mm}$, when soil water content is at field capacity), and $p$ the fraction of $S_{\max }$ that a crop can extract from the root zone without suffering water stress, which is a function of $\mathrm{ET}_{0}$ and $K_{\mathrm{c}}$ (Allen et al., 1998).

WF of the four crops in the YRB was estimated covering both rain-fed and irrigated agriculture. In the case of rain-fed crop production, blue CWU is zero and green CWU $\left(\mathrm{m}^{3} \mathrm{ha}^{-1}\right)$ was calculated by aggregating the daily values of ET over the length of the growing period. In the case of irrigated crop production, green CWU was assumed to be equal to the ET for the case without irrigation. The blue CWU was estimated as the actual ET for the case with sufficient irrigation minus the green CWU (Mekonnen and Hoekstra, 2010, 2011).

The crop yield is influenced by water stress (Mekonnen and Hoekstra, 2010). The actual harvested yield $\left(Y, \mathrm{t} \mathrm{ha}^{-1}\right)$ at the end of crop-growing period for each grid cell was estimated using the equation proposed by Doorenbos and Kassam (1979):
$Y=Y_{\mathrm{m}} \times\left[1-K_{\mathrm{y}}\left(1-\frac{\sum_{d=1}^{\mathrm{lgp}} \mathrm{ET}}{\mathrm{CWR}}\right)\right]$,

where $Y_{\mathrm{m}}$ is the maximum yield $\left(\mathrm{tha}^{-1}\right)$, obtained by multiplying the corresponding provincial average yield values by a factor of 1.2 (Reynolds et al., 2000). $K_{\mathrm{y}}$ is the yield response factor obtained from Doorenbos and Kassan (1979). CWR refers to the crop water requirement for the whole growing period $\left(\mathrm{mm} \mathrm{period}^{-1}\right)$ (which is equal to $\left.K_{\mathrm{c}} \times \mathrm{ET}_{0}\right)$.

\subsection{Sensitivity and uncertainty analysis}

The estimation of crop WF requires a number of input variables and parameters to the model, including daily precipitation (PR), daily reference evapotranspiration $\left(\mathrm{ET}_{0}\right)$, crop coefficients $\left(K_{\mathrm{c}}\right)$ in the different growing stages, crop calendar (planting date and length of the growing period), soil water content at field capacity $\left(S_{\max }\right)$, yield response factor $\left(K_{\mathrm{y}}\right)$ and maximum yield $\left(Y_{\mathrm{m}}\right)$. The one-at-a-time method (see below) was applied to investigate the sensitivity of CWU, $Y$ and WF to changes in these inputs. The uncertainties in WF due to uncertainties in PR, $\mathrm{ET}_{0}, K_{\mathrm{c}}$, and crop calendar were assessed through Monte Carlo simulations. We assumed that systematic errors in original climate observations at stations had been removed already. Uncertainties in variables PR, $\mathrm{ET}_{0}$ and $K_{\mathrm{c}}$ were assumed random, independent and close to a normal (Gaussian) distribution (Ahn, 1996; Xu et al., 2006a; Droogers and Allen, 2002; Meyer et al., 1989; Troutman, 1985).

\subsubsection{Sensitivity analysis}

The "one-at-a-time" or "sensitivity curve" method is a simple but practical way of sensitivity analysis to investigate the response of an output variable to variation of input values (Hamby, 1994; Sun et al., 2012). With its simplicity and intuitionism, the method is popular and has been widely used (Ahn, 1996; Goyal, 2004; Xu et al., 2006a, b; Estévez et al., 2009). The method was performed by introducing fractional changes to one input variable, while keeping other 
inputs constant. The sensitivity curve of the resultant relative change in the output variable was then plotted against the relative change of the input variable. The sensitivity analysis was carried out for each year in the period 1996-2005. For each cropped grid cell, we varied each input variable within a certain range. Then, the annual average level of the responses in CWU, $Y$, and (green, blue, and total) WF of the crops for the basin as a whole were recorded. With respect to the input variables PR, $\mathrm{ET}_{0}$ and $K_{\mathrm{c}}$, we shifted each within the range of $\pm 2 \mathrm{SD}$ ( $2 \times$ standard deviation of input uncertainties), which represents the $95 \%$ confidence interval for uncertainties in the input variable. In terms of the crop calendar, we varied the planting date $(D)$ within \pm 30 days of constant growing degree days (GDD) and relative length of crop-growing stages (Allen et al., 1998) (Table 1). The cumulative GDD ( ${ }^{\circ}$ day), measuring heat units during crop growth, has vastly improved expression and prediction of the crop's phenological cycle compared to other approaches, such as time of the year or number of days (McMaster and Wilhelm, 1997). In the study, a crop's GDD was calculated per year, following the most widely used "Method 1" (McMaster and Wilhelm, 1997), by summing the difference of the daily base temperature and the average air temperature over the reference crop-growing period in days (Table 1). The base temperature is the temperature below which crop growth does not progress. The base temperature of each crop was obtained from FAO (Raes et al., 2012). Parameters $S_{\max }, K_{\mathrm{y}}$ and $Y_{\mathrm{m}}$ were varied within the range of $\pm 20 \%$ of the default value.

\subsubsection{Uncertainty analysis}

The advantage of uncertainty analysis with the Monte Carlo (MC) simulation is that the model to be tested can be of any complexity (Meyer, 2007). MC simulations were carried out at the basin level to quantify the uncertainties in estimated WF due to uncertainties in individual or multiple input variables. The uncertainty analysis was carried out separately for 3 years within the study period: 1996 (wet year), 2000 (dry year), and 2005 (average year). For each MC simulation, 1000 runs were performed. Based on the set of WF estimates from those runs, the mean $(\mu)$ and standard deviation (SD) is calculated; with $95 \%$ confidence, WF falls in the range of $\mu \pm 2 \mathrm{SD}$. The SD will be expressed as a percentage of the mean.

\subsubsection{Input uncertainty}

\section{Uncertainty in precipitation (PR)}

Uncertainties in the Climate Research Unit Time Series (CRU-TS) (Harris et al., 2014) grid precipitation values used for WF accounting in this study come from two sources: the measurement errors inherent in station observations, and errors which occur during the interpolation of station data in constructing the grid database (Zhao and Fu, 2006; Fekete et al., 2004; Phillips and Marks, 1996). Zhao and Fu (2006) compared the spatial distribution of precipitation as in the CRU database with the corresponding observations over China and revealed that the differences between the CRU data and observations vary from -20 to $20 \%$ in the area where the YRB is located. For this study, we assume a $\pm 20 \%$ range around the CRU precipitation data as the $95 \%$ confidence interval $(2 \mathrm{SD}=20 \%)$.

\section{Uncertainty in reference evapotranspiration $\left(\mathbf{E T}_{\mathbf{0}}\right)$}

The uncertainties in the meteorological data used in estimating $\mathrm{ET}_{0}$ will be transferred into uncertainties in the $\mathrm{ET}_{0}$ values. The method used to estimate the CRU-TS ET 0 data set is the Penman-Monteith (PM) method (Allen et al., 1998). The PM method has been recommended (Allen et al., 1998) for its high accuracy at station level within $\pm 10 \%$ from the actual values under all ranges of climates (Jensen et al., 1990). With respect to the gridded $\mathrm{ET}_{0}$ calculation, the interpolation may cause additional error (Thomas, 2008; Phillips and Marks, 1996). There is no detailed information on uncertainty in the CRU-TS $\mathrm{ET}_{0}$ data set. We estimated daily $\mathrm{ET}_{0}$ values $\left(\mathrm{mm} \mathrm{day}^{-1}\right.$ ) for the period 1996-2005 from observed climatic data at 24 meteorological stations spread out in the YRB (CMA, 2008) by the PM method. Then we compared, station by station, the monthly averages of those calculated daily $\mathrm{ET}_{0}$ values to the corresponding monthly $\mathrm{ET}_{0}$ values in the CRU-TS data set (Fig. 1a). The differences between the station values and CRU-TS values ranged from -0.23 to $0.27 \mathrm{~mm} \mathrm{day}^{-1}$ with a mean of $0.005 \mathrm{~mm} \mathrm{day}^{-1}$ (Fig. 1b). The standard deviation (SD) of the differences was $0.08 \mathrm{~mm} \mathrm{day}^{-1}, 5 \%$ from the station values, which implies an uncertainty range of $\pm 10 \%$ ( $2 \mathrm{SD}$ ) at $95 \%$ confidence interval. The locations of CMA stations were different from the stations used for generating the CRU data set (Harris et al., 2014) (see Fig. 1c), which was one of the sources of the uncertainty. We added the basin level uncertainty in monthly $\mathrm{ET}_{0}$ values due to uncertainties in interpolation $( \pm 10 \%$ at $95 \%$ confidence level) and the uncertainty related to the application of the PM method (another $\pm 10 \%$ at $95 \%$ confidence level) to arrive at an overall uncertainty of $\pm 20 \%$ (2 SD) for the $\mathrm{ET}_{0}$ data. We acknowledge that this is a crude estimate of uncertainty, but there is no better method.

\section{Uncertainty in crop characteristics}

We used the $K_{\mathrm{c}}$ values from Table 1 for the whole basin. According to Jagtap and Jones (1989), the $K_{\mathrm{c}}$ value for a certain crop can vary by $15 \%$. We adopted this value and assumed the $95 \%$ uncertainty range falls within $\pm 15 \%$ ( $2 \mathrm{SD}$ ) from the mean $K_{\mathrm{c}}$ values. Referring to the crop calendar, we assumed that the planting date for each crop fluctuated within \pm 30 days from the original planting date used, holding the same length of GDD for each year. Table 2 summarises the uncertainty scenarios considered in the study. 


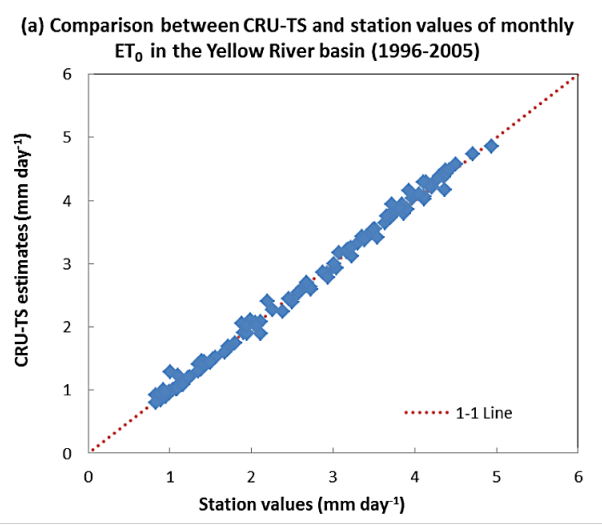

(b) Distribution of the differences between CRU-TS $\mathrm{ET}_{0}$ and

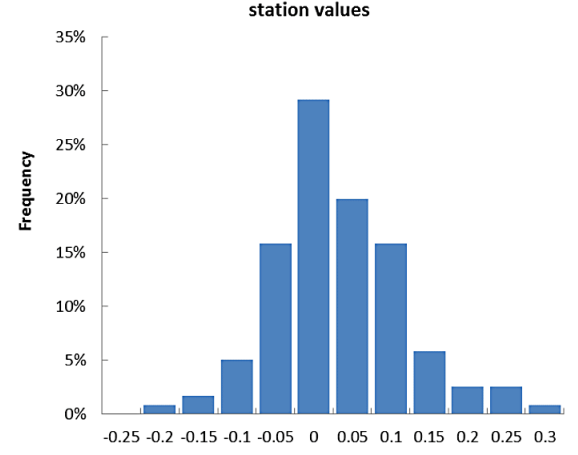

( $m m$ day $\left.^{-1}\right)$

(c) The station locations for CMA data and CRU data.

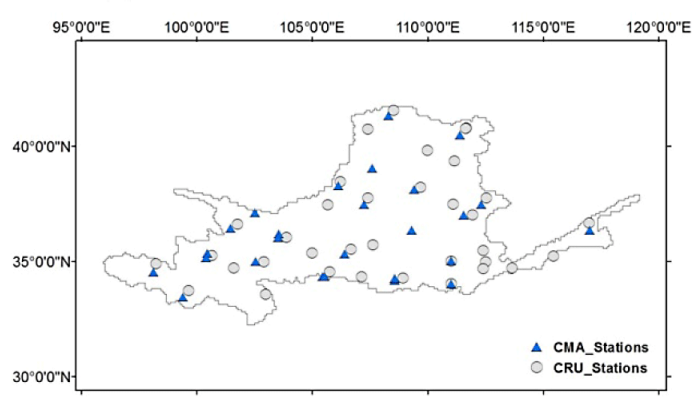

Figure 1. Differences between monthly averages of daily $\mathrm{ET}_{0}$ data from CRU-TS and station-based values for the Yellow River basin, 1996-2005.

\subsection{Data}

The GIS polygon data for the YRB were extracted from the HydroSHEDS data set (Lehner et al., 2008). Total monthly PR, monthly averages of daily $\mathrm{ET}_{0}$, number of wet days, and daily minimum and maximum temperatures at 30 by 30 arcmin resolution for 1996-2005 were extracted from CRU-TS-3.10 and 3.10.01 (Harris et al., 2014). Figure 2 shows $\mathrm{PR}$ and $\mathrm{ET}_{0}$ for the YRB in the study period. Daily values of precipitation were generated from the monthly values using the CRU-dGen daily weather generator model (Schuol and Abbaspour, 2007). Daily $\mathrm{ET}_{0}$ values were derived from monthly average values by curve fitting to the monthly average through polynomial interpolation (Mekonnen and Hoekstra, 2011). Data on irrigated and rainfed areas for each crop at a 5 by 5 arcmin resolution were obtained from the MIRCA2000 data set (Portmann et al., 2010). Crop areas and yields within the YRB from MIRCA2000 were scaled to fit yearly agriculture statistics per province of China (MAPRC, 2009; NBSC, 2006, 2007). Total available soil water capacity at a spatial resolution of 5 by 5 arcmin was obtained from the ISRIC-WISE version 1.2 data set (Batjes, 2012).

\section{Results}

\subsection{Sensitivity of CWU, $Y$, and WF to variability of input variables}

\subsubsection{Sensitivity to variability of precipitation (PR)}

The average sensitivities of CWU, $Y$, and WF to variability of precipitation for the study period were assessed by varying the precipitation between $\pm 20 \%$ as shown in Fig. 3. An overestimation in precipitation leads to a small overestimation of green WF and a relatively large underestimation of blue WF. A similar result was found for maize in the Po Valley of Italy by Bocchiola et al. (2013). The sensitivity of WF to input variability is defined by the combined effects on the CWU and $Y$. Figure 3 shows the overall result for the YRB, covering both rain-fed and irrigated cropping.

For irrigated agriculture, a reduction in green $\mathrm{CWU}$ due to smaller precipitation will be compensated with an increased blue CWU, keeping total CWU and $Y$ unchanged. Therefore, the changes in $Y$ were due to the changes in the yields in rain-fed agriculture. The relative changes in total WF were always smaller than $\pm 5 \%$ because of the opposite direction of sensitivities of green and blue WF, as well as the domination of green WF in the total. In addition, in terms of wheat only, both $Y$ and total WF decreased with less precipitation. Purposes of modern agriculture are mainly keeping or improving the crop production as well as reducing water use. The instance for wheat indicates that $Y$ (mass of a crop per hectare) might decrease in certain climate situations in practice although the WF (referring to drops of water used per mass of crop) decreased. On the other hand, it can be noted that the sensitivity of CWU, $Y$, and WF to input variability differs across crop types, especially evident in blue WF. Regarding the four crops considered, blue WF of soybean is most sensitive to variability in precipitation and blue WF of rice is least sensitive. The explanation lies in the share of blue WF in total WF. At basin level, the blue WF of soybean accounted for about $9 \%$ of the total WF, while the blue WF of rice was around $44 \%$ of the total, which is the highest blue water fraction among the four crops. The larger sensitivity of the blue WF of soybean to change in precipitation compared 

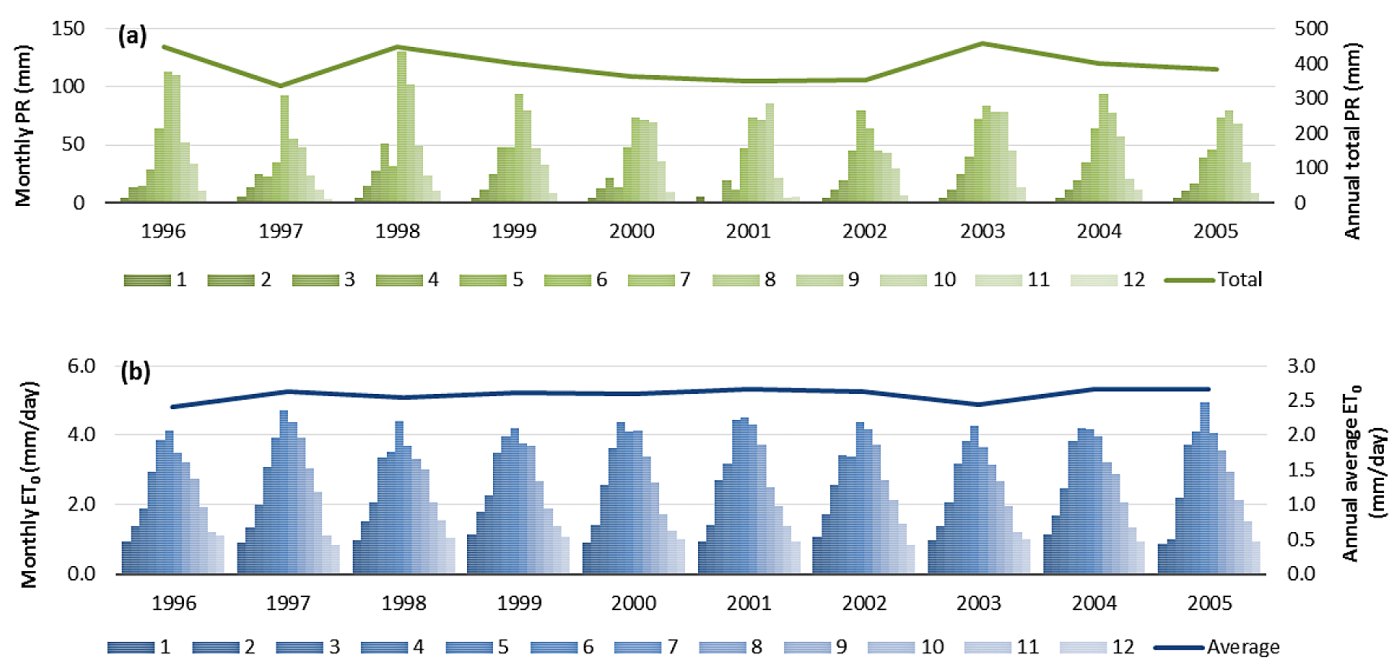

Figure 2. Monthly precipitation (PR) and monthly averages of daily reference evapotranspiration (ET $\mathrm{ET}_{0}$ ) in the Yellow River basin from the CRU-TS database, for the period 1996-2005.
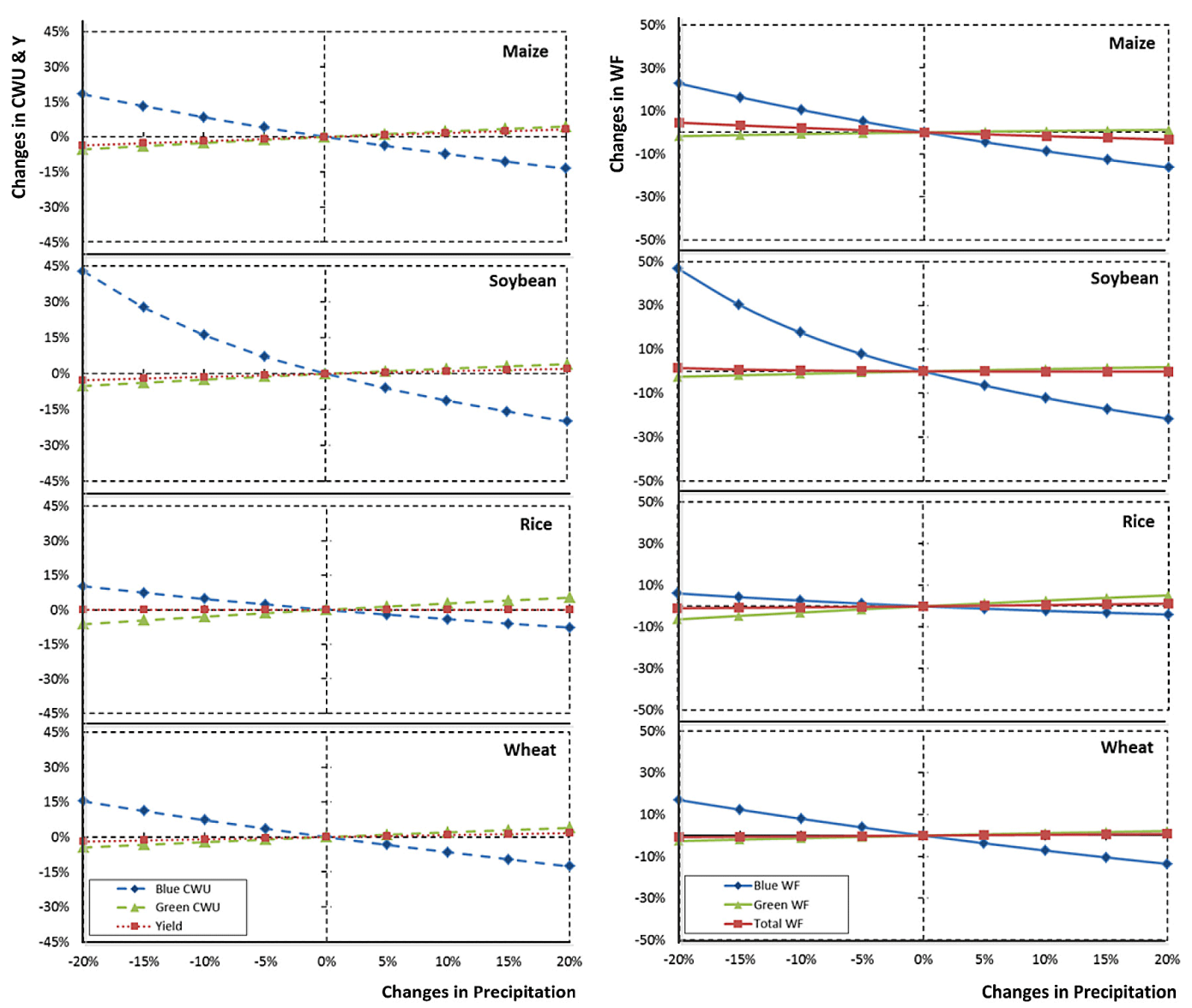

Figure 3. Sensitivity of CWU, $Y$ and WF to changes in precipitation (PR), 1996-2005. 

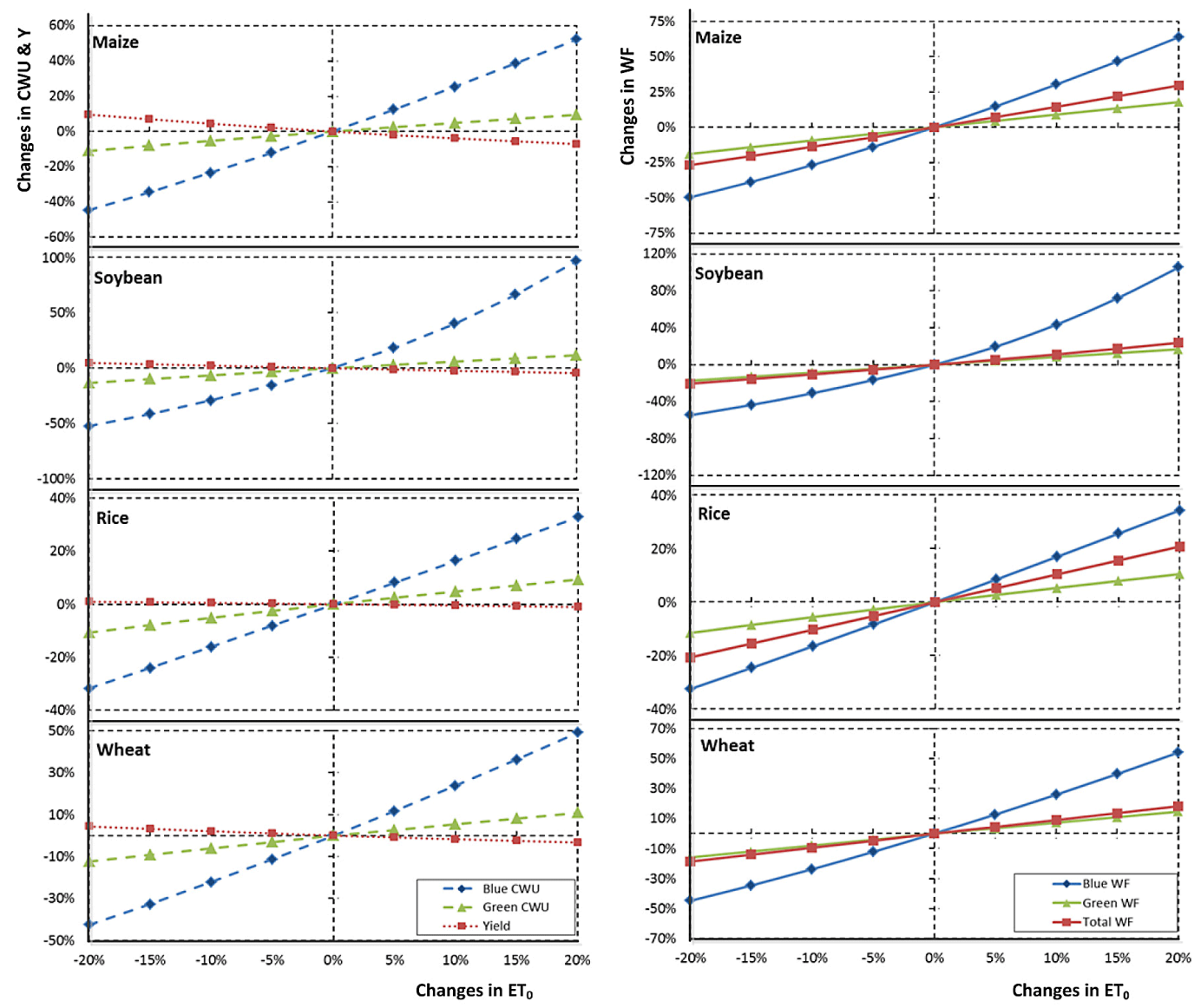

Figure 4. Sensitivity of CWU, $Y$ and WF to changes in reference evapotranspiration $\left(\mathrm{ET}_{0}\right), 1996-2005$.

to that of rice shows that the smaller the blue water footprint, the larger its sensitivity to a marginal change in precipitation.

\subsubsection{Sensitivity to variability of $\mathrm{ET}_{0}$ and $K_{\mathrm{c}}$}

Figure 4 shows the average sensitivity of CWU, $Y$, and WF to changes in $\mathrm{ET}_{0}$ within a range of $\pm 20 \%$ from the mean for the period 1996-2005. The influences of changes in $\mathrm{ET}_{0}$ on WF are greater than the effect of changes in precipitation. Both green and blue $\mathrm{CWU}$ increase with the rising $\mathrm{ET}_{0}$. An increase in $\mathrm{ET}_{0}$ will increase the crop water requirement. For rain-fed crops, the crop water requirement may not be fully met, leading to crop water stress and thus lower $Y$. For irrigated crops under full irrigation, the crop will not face any water stress, so that the yield will not be affected. The decline in yield at increasing $\mathrm{ET}_{0}$ at basin level in Fig. 4 is therefore due to yield reductions in rain-fed agriculture only.

Due to the combined effect of increasing CWU and decreasing $Y$ at increasing $\mathrm{ET}_{0}$, an overestimation in $\mathrm{ET}_{0}$ leads to a larger overestimation of WF. The strongest effect of $\mathrm{ET}_{0}$ changes on blue WF was found for soybean, with a relative increase reaching up to $105 \%$ with a $20 \%$ increase in $\mathrm{ET}_{0}$, while the lightest response was found for the case of rice, with a relative increase in blue WF of $34 \%$. The sensitivities of green WF were similar among the four crops. The changes in total WF were always smaller and close to $\pm 30 \%$ in the case of a $\pm 20 \%$ change in $\mathrm{ET}_{0}$.

As shown in Eq. (4), $K_{\mathrm{c}}$ and $\mathrm{ET}_{0}$ have the same effect on crop evapotranspiration. Therefore, the effects of changes in $K_{\mathrm{c}}$ on CWU, $Y$, and WF are exactly the same as the effects of $\mathrm{ET}_{0}$ changes. The changes in total WF were less than $\pm 25 \%$ in the case of a $\pm 15 \%$ change in $K_{\mathrm{c}}$ values.

\subsubsection{Sensitivity to changing crop planting date $(D)$}

The responses of CWU, $Y$, and WF to the change of the crop planting date with constant GDD are plotted in Fig. 5. There is no linear relationship between the cropping calendar and WF. Therefore, no generic information can be summarized for the sensitivity of WF of crops to a changing cropping calendar. But some interesting regularity can still be found. With the late sowing dates, the crop-growing periods in days became longer for rice and soybean, while shorter for maize and wheat. WF was smaller with late planting date for all four crops, which is mainly due to the decrease in the blue and green CWU for maize, rice and wheat, as well as a relatively 
Table 2. Input uncertainties for crop water footprint accounting in the Yellow River basin.

\begin{tabular}{llll}
\hline Input variable & Unit & $\begin{array}{l}95 \% \text { confidence } \\
\text { interval of input } \\
\text { uncertainties }\end{array}$ & $\begin{array}{l}\text { Distribution of } \\
\text { input uncertainties }\end{array}$ \\
\hline Precipitation $(\mathrm{PR})$ & $\mathrm{mm} \mathrm{day}^{-1}$ & $\pm 20 \%\left(2 \mathrm{SD}^{*}\right)$ & Normal \\
Reference evapotranspiration $\left(\mathrm{ET}_{0}\right)$ & $\mathrm{mm} \mathrm{day}^{-1}$ & $\pm 20 \%(2 \mathrm{SD})$ & Normal \\
Crop coefficient $\left(K_{\mathrm{c}}\right)$ & - & $\pm 15 \%(2 \mathrm{SD})$ & Normal \\
Planting date $(D)$ & days & \pm 30 & Uniform (discrete) \\
\hline
\end{tabular}

* 2 SD: $2 \times$ standard deviation of input uncertainties.
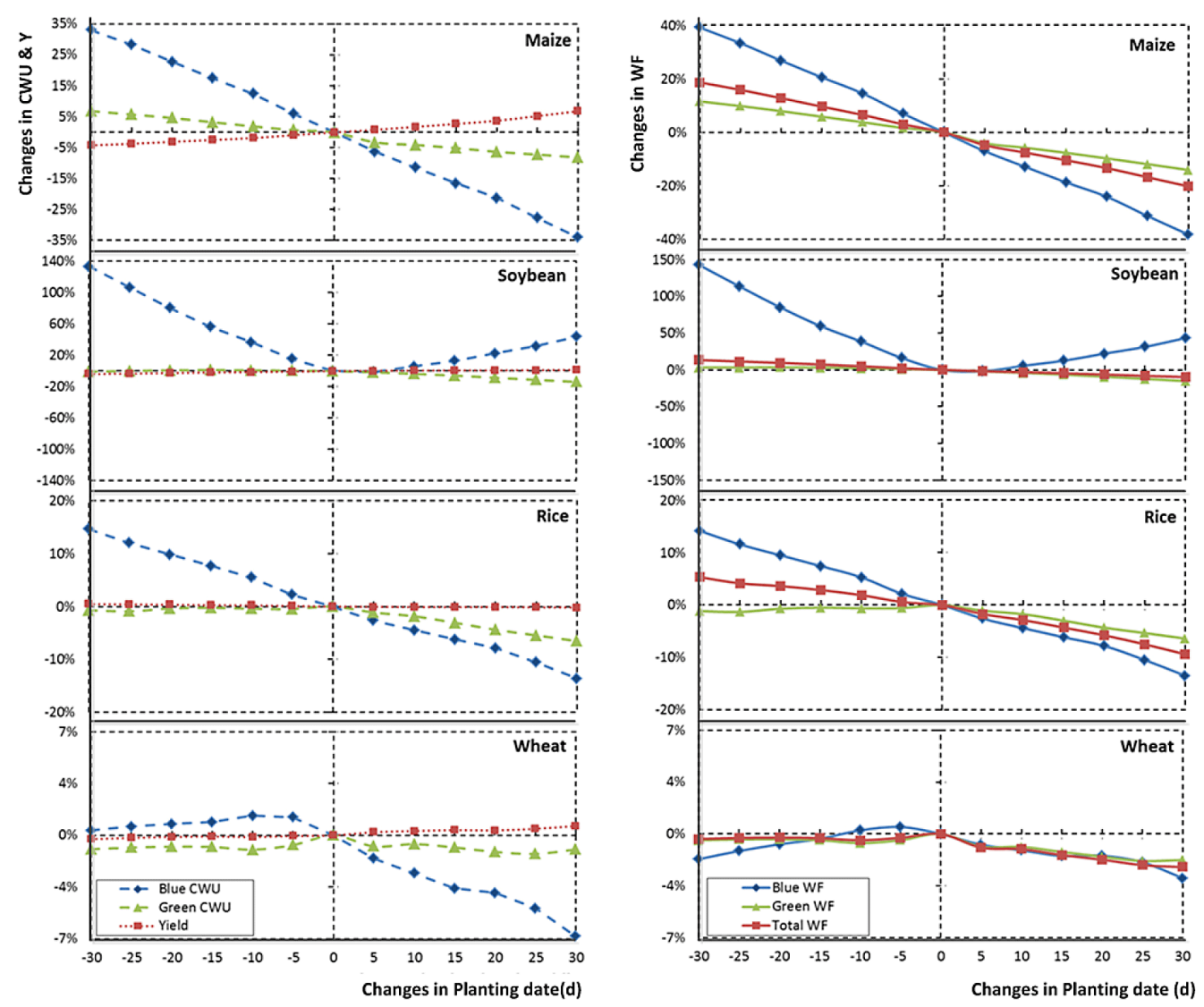

Figure 5. Sensitivity of CWU, $Y$ and WF to changes in crop planting date $(D), 1996-2005$.

larger decrease of green CWU for soybean. Apparently, the reduction in CWU of maize and wheat was due to a shortening of the growing period. Meanwhile, we found a reduced $\mathrm{ET}_{0}$ over the growing period with delayed planting of the rice and soybean, which led to a decrease in the crop water requirement. This is consistent with the result observed for maize in the western Jilin Province of China by Qin et al. (2012) and northern China (Jin et al., 2012; Sun et al., 2007) based on local field experiments. Late planting, particularly for maize, rice and wheat, could save water, particularly blue water, while increasing $Y$. The response of wheat yield did not match with the field experiment results in northern China by Sun et al. (2007). The difference was because they set a constant growing period when changing the sowing date of wheat, not taking the GDD into consideration. With late planting of soybean, the reduction of PR was larger than the reduction of crop water requirement of soybean, resulting in a larger blue WF. Since blue WF is more sensitive to $\mathrm{ET}_{0}$ and PR than green WF, the relative change in blue WF was always more than green WF. When planted earlier, both green and blue WF of maize increased because of increased CWU with a longer growing period. Although growing periods for 

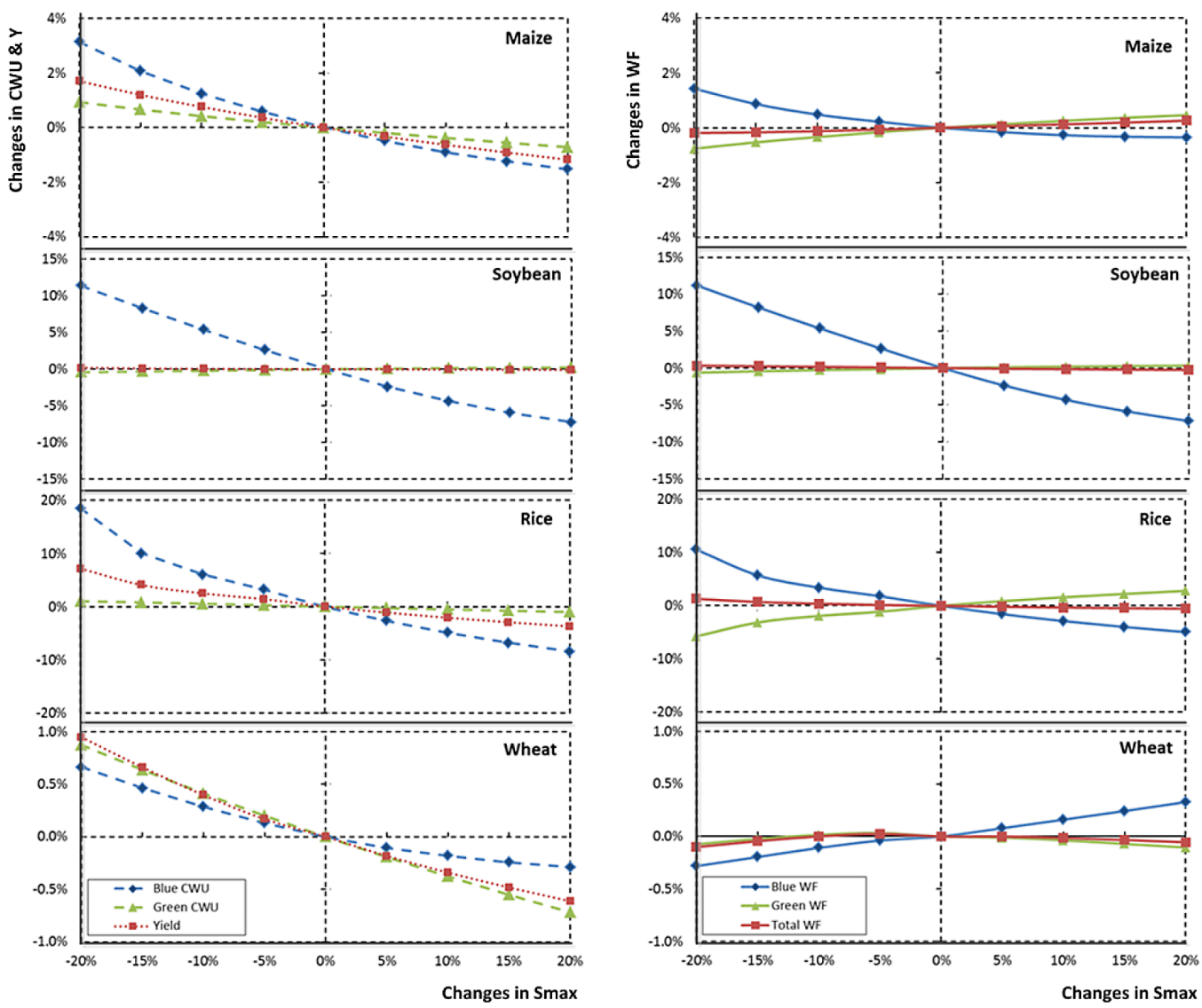

Figure 6. Sensitivity of CWU, $Y$ and WF to changes in the field capacity of the soil water $\left(S_{\max }\right), 1996-2005$.

rice and soybean were shorter with earlier sowing, the increased rainwater deficit resulted in more blue CWU and less green CWU for irrigated fields and a slight increase in total WF with little change in $Y$. Meanwhile, a different response curve was observed for wheat with earlier planting. The explanation for the unique sensitivity curve for wheat is that the crop is planted in October after the rainy season (June to September) and the growing period lasts around 335 days (Table 1), which leads to a low sensitivity to the precise planting date. However, as interesting as the phenomenon found in Fig. 3, the $Y$ and total WF both dropped (by 0.25 and $0.3 \%$ to 30 days earlier planting, respectively) when the planting date was shifted by more than 15 days earlier than the reference sowing date of wheat. A similar instance also arose for rice with a delayed sowing date: reduction of $Y$ by $0.2 \%$ and total WF by $9.3 \%$ when delaying the planting day by 30 days.

Therefore from perspective of the agricultural practice, the response of both crop production and crop water consumption with change in the planting date should be considered in agricultural water-saving projects. In general, the results show that the crop calendar is one of the factors affecting the magnitude of crop water consumption. A proper planning of the crop-growing period is, therefore, vital from the perspective of water resources use, especially in arid and semi-arid areas like the YRB. However, our estimate, which was based on a sensitivity analysis by keeping all other input parameters such as the initial soil water content constant, could be different from the actual cropping practice. There are techniques to maintain or increase the initial soil moisture, for instance by storing off-season rainfall (through organic matter) in the cropping field.

\subsubsection{Sensitivity to changes of soil water content at field capacity $\left(S_{\max }\right)$}

The sensitivity curves of CWU, $Y$ and WF to the changes of the $S_{\max }$ within $\pm 20 \%$ are shown in Fig. 6 . The total WF varied no more than $1.3 \%$ to changes in the $S_{\max }$. The maximum sensitivity was found for rice. But the responses of blue and green WF were different per crop type. Blue WF decreased, while green WF increased with higher $S_{\max }$ for maize, soybean, and rice. For wheat we found the opposite. Figure 6 shows that CWU and $Y$ become smaller with higher $S_{\max }$. In the model, higher $S_{\max }$ with no change in the soil moisture defines a higher water stress in crop growth, resulting in smaller $K_{\mathrm{S}}$, ET (Eqs. 4 and 5), and thus lower $Y$ (Eq. 6). 


\subsubsection{Sensitivity to parameters for yield simulation}

The yield response factor $\left(K_{\mathrm{y}}\right)$ and maximum yield $\left(Y_{\mathrm{m}}\right)$ are important parameters defining the $Y$ simulation (Eq. 6). They are always set with a constant default value for different crops. It is clear from the equation that crop WF is negatively correlated to $Y_{\mathrm{m}}$ : a $20 \%$ increase in $Y_{\mathrm{m}}$ results in a $20 \%$ increase in $Y$ and a $20 \%$ decrease in the WFs. Figure 7 shows the sensitivity of $Y$ and WF of each crop to changes in the values of $K_{\mathrm{y}}$ within $\pm 20 \%$ of the default value. The figure shows that an increase in $K_{\mathrm{y}}$ leads to a decrease in simulated $Y$ and an increase in the WFs. Due to the difference in the sensitivity of crops to water stress, different crops have different default $K_{\mathrm{y}}$ values, leading to different levels of sensitivity in $Y$ and WF estimates to changes in $K_{\mathrm{y}}$ with crop types. Among the four crops, maize had the highest, while wheat had the lowest sensitivity in $Y$ and WF to the variation of $K_{\mathrm{y}}$.

\subsection{Annual variation of sensitivities in crop water footprints}

As an example of the annual variation of sensitivities, Table 3 presents the sensitivity of blue, green and total WF of maize to changes in PR, $\mathrm{ET}_{0}, K_{\mathrm{c}}, D, S_{\mathrm{max}}$, and $K_{\mathrm{y}}$ for each specific year in the period 1996-2005. As can be seen from the table, the sensitivity of green WF to the PR, $\mathrm{ET}_{0}, K_{\mathrm{c}}, D$, and $S_{\max }$ was relatively stable around the mean annual level. But there was substantial inter-annual fluctuation of sensitivity of blue WF for all four crops. For each year and each crop, the slope $(S)$ of the sensitivity curve of change in blue WF versus change in PR, $\mathrm{ET}_{0}$, and $K_{\mathrm{c}}$ was computed, measuring the slope at mean values for $\mathrm{PR}, \mathrm{ET}_{0}$, and $K_{\mathrm{c}}$. The slopes (representing the percentage change in blue WF over percentage change in input variable) are plotted against the corresponding blue WF (Fig. 8). The results show that - most clearly for maize and rice - the smaller the annual blue WF, the higher the sensitivity to changes in $\mathrm{PR}, \mathrm{ET}_{0}$, or $K_{\mathrm{c}}$. As shown by the straight curves through the data for maize (Fig. 8), we can roughly predict the sensitivity of blue WF to changes in input variables based on the size of blue WF itself. The blue WF of a specific crop in a specific field will be more sensitive (in relative terms) to the three inputs in wet years than in dry years, simply because the blue WF will be smaller in a wet year.

\subsection{Uncertainties in WF per unit of crop due to input uncertainties}

In order to assess the uncertainty in WF (in $\mathrm{m}^{3} \mathrm{t}^{-1}$ ) due to input uncertainties, Monte Carlo (MC) simulations were performed at the basin level for 1996 (wet year), 2000 (dry year), and 2005 (average year). For each crop, we carried out a MC simulation for four input uncertainty scenarios, considering the effect of: (1) uncertainties in PR alone, (2) uncertainties
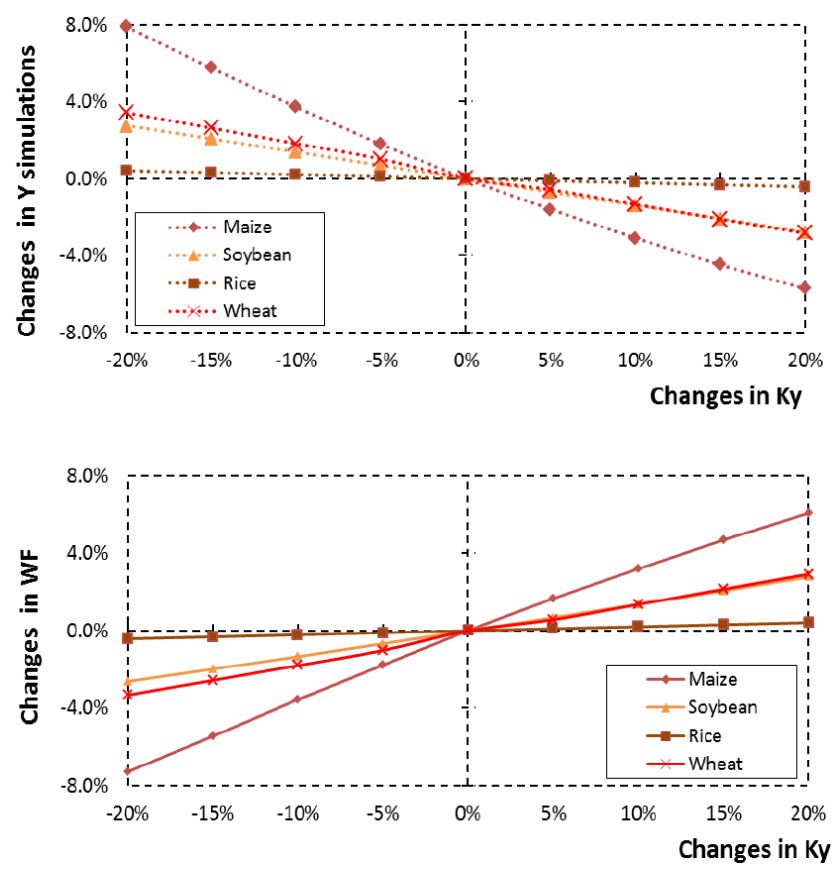

Figure 7. Sensitivity of $Y$ and WF to changes in yield response factor $\left(K_{\mathrm{y}}\right), 1996-2005$.

in $\mathrm{ET}_{0}$ alone, (3) combined uncertainties in the two climatic input variables ( $\left.\mathrm{PR}+\mathrm{ET}_{0}\right)$, and (4) combined uncertainties in all four key input variables considered in this study $\left(\mathrm{PR}+\mathrm{ET}_{0}+K_{\mathrm{c}}+D\right)$. The uncertainty results in blue, green and total WF of the four crops for the four scenarios and 3 years are shown in Table 4 . The uncertainties are expressed in terms of values for $2 \mathrm{SD}$ as a percentage of the mean value; the range of \pm 2 SD around the mean value gives the $95 \%$ confidence intervals.

In general, for all uncertainty scenarios, blue WF shows higher uncertainties than green WF. Uncertainties in green WF are similar for the 3 different hydrologic years. Uncertainties in blue WF are largest (in relative sense) in the wet year, conform our earlier finding that blue WF is more sensitive to changes in input variables in wet years. The uncertainties in WF due to uncertainties in PR are much smaller than the uncertainties due to uncertainties in $\mathrm{ET}_{0}$. Uncertainties in PR hardly affect the assessment of total WF of crops in all 3 different hydrologic years. Among the four crops, soybean has the highest uncertainty in green and blue WF. The uncertainty in total WF for all crops is within the range of \pm 18 to $20 \%$ (at $95 \%$ confidence interval) when looking at the effect of uncertainties in the two climate input variables only, and within the range of \pm 28 to $32 \%$ (again at $95 \%$ confidence interval) when looking at the effect of uncertainties in all four input variables considered. In all cases, the most important uncertainty source is the value of $\mathrm{ET}_{0}$. Figure 9 shows, for maize as an example, the probability distribution of the total WF (in $\mathrm{m}^{3} \mathrm{t}^{-1}$ ) given the uncertainties in the two climatic input variables and all four input variables combined. 

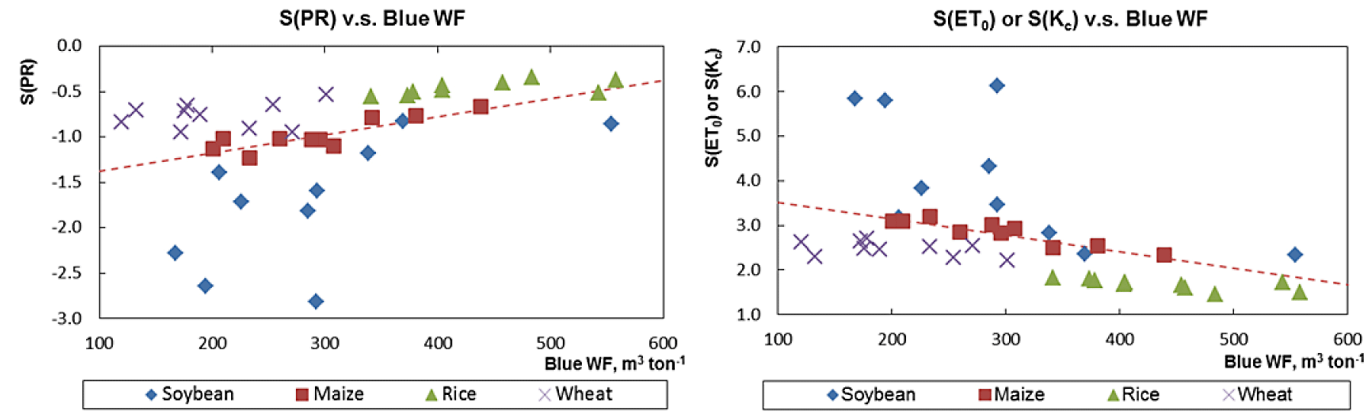

Figure 8. The slope $(S)$ of the sensitivity curve for the blue WF for each crop for each year in the period 1996-2005 (vertical axis) plotted against the blue WF of the crop in the respective year ( $x$ axis). The graph on the left shows the relative sensitivity of blue WF to PR; the graph on the right shows the relative sensitivity of blue WF to $\mathrm{ET}_{0}$ or $K_{\mathrm{c}}$. The sensitivities to $\mathrm{ET}_{0}$ and $K_{\mathrm{c}}$ were the same. The trend lines in both graphs refer to the data for maize.
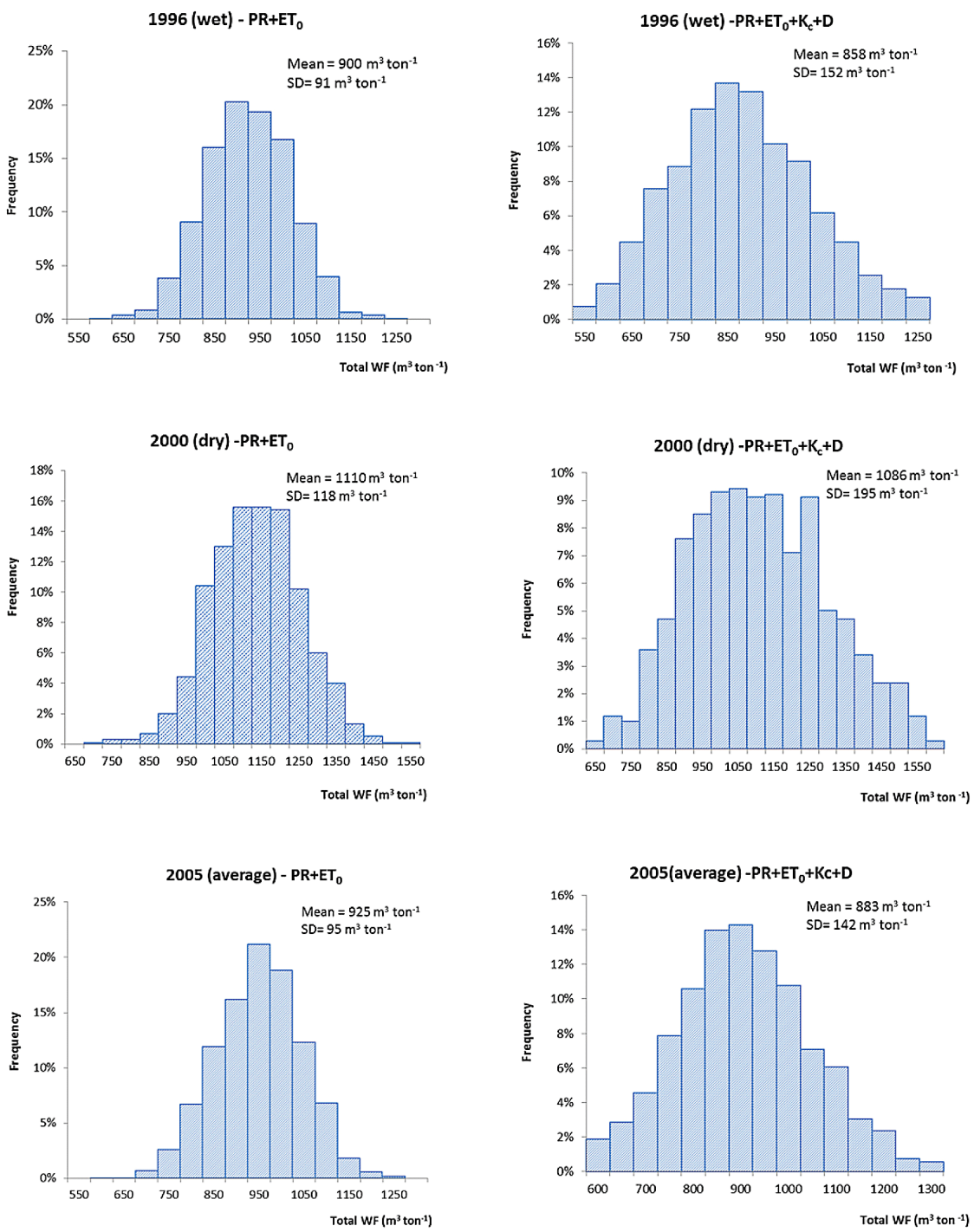

Figure 9. Probability distribution of the total WF of maize given the combined uncertainties in $\mathrm{PR}$ and $\mathrm{ET}_{0}$ (graphs at the left) and given the combined uncertainties in PR, $\mathrm{ET}_{0}, K_{\mathrm{c}}$ and $D$ (graphs at the right), for the years 1996, 2000 and 2005. 
Table 3. Sensitivity of annual water footprint (WF) of maize to input variability at the level of the Yellow River basin, for the period 1996-2005.

\begin{tabular}{|c|c|c|c|c|c|c|c|c|c|c|c|c|c|}
\hline & \multirow{3}{*}{$\begin{array}{c}\text { WF } \\
\left(\mathrm{m}^{3} \mathrm{t}^{-1}\right)\end{array}$} & \multicolumn{12}{|c|}{ Changes in the WF to variability of input variables (\%) } \\
\hline & & \multicolumn{2}{|c|}{ PR } & \multicolumn{2}{|c|}{$\mathrm{ET}_{0}$} & \multicolumn{2}{|c|}{$K_{\mathrm{c}}$} & \multicolumn{2}{|c|}{$D$} & \multicolumn{2}{|c|}{$S_{\max }$} & \multicolumn{2}{|c|}{$K_{\mathrm{y}}$} \\
\hline & & $-20 \%$ & $20 \%$ & $-20 \%$ & $20 \%$ & $-15 \%$ & $15 \%$ & $-30 \mathrm{~d}$ & $30 \mathrm{~d}$ & $-20 \%$ & $20 \%$ & $-20 \%$ & $20 \%$ \\
\hline \multicolumn{14}{|c|}{ Blue WF } \\
\hline 1996 & 201 & 27 & -18 & -52 & 72 & -41 & 52 & 51 & -51 & -3.2 & 1.4 & -4.1 & 4.1 \\
\hline 1997 & 381 & 17 & -14 & -47 & 55 & -36 & 41 & 19 & -25 & 0.9 & 0.9 & -9.4 & 8.0 \\
\hline 1998 & 209 & 25 & -16 & -53 & 70 & -42 & 51 & 31 & -42 & 4.1 & -1.6 & -5.6 & 4.8 \\
\hline 1999 & 308 & 26 & -18 & -50 & 67 & -39 & 49 & 44 & -42 & 1.9 & -1.3 & -7.5 & 6.2 \\
\hline 2000 & 342 & 18 & -14 & -46 & 54 & -35 & 40 & 48 & -45 & 0.6 & 0.3 & -8.6 & 6.8 \\
\hline 2001 & 439 & 15 & -12 & -44 & 50 & -34 & 37 & 38 & -33 & 0.4 & 0.8 & -9.8 & 7.4 \\
\hline 2002 & 296 & 23 & -18 & -51 & 62 & -39 & 46 & 23 & -24 & 6.7 & -3.1 & -5.8 & 5.1 \\
\hline 2003 & 233 & 29 & -21 & -56 & 72 & -44 & 53 & 45 & -41 & 0.8 & 0.3 & -4.9 & 5.0 \\
\hline 2004 & 260 & 24 & -17 & -49 & 65 & -39 & 47 & 51 & -43 & 1.0 & -0.1 & -7.2 & 6.4 \\
\hline 2005 & 288 & 25 & -17 & -50 & 71 & -39 & 51 & 39 & -37 & 1.2 & -1.0 & -9.9 & 6.9 \\
\hline Mean & 295 & 23 & -16 & -50 & 64 & -39 & 47 & 39 & -38 & 1.4 & -0.3 & -7.3 & 6.1 \\
\hline \multicolumn{14}{|c|}{ Green WF } \\
\hline 1996 & 754 & -1.4 & 0.9 & -18 & 18 & -14 & 14 & 12 & -17 & -0.5 & 0.2 & -4.1 & 4.1 \\
\hline 1997 & 820 & -2.0 & 1.3 & -19 & 18 & -14 & 13 & 10 & -14 & -1.0 & 0.6 & -9.4 & 8.0 \\
\hline 1998 & 792 & -1.3 & 0.7 & -19 & 18 & -14 & 14 & 12 & -11 & -0.8 & 0.4 & -5.6 & 4.8 \\
\hline 1999 & 864 & -2.1 & 1.3 & -19 & 18 & -14 & 13 & 12 & -13 & -0.8 & 0.6 & -7.5 & 6.2 \\
\hline 2000 & 831 & -2.0 & 1.3 & -19 & 18 & -14 & 13 & 12 & -15 & -0.8 & 0.5 & -8.6 & 6.8 \\
\hline 2001 & 819 & -2.3 & 1.7 & -19 & 17 & -14 & 13 & 11 & -15 & -0.8 & 0.5 & -9.8 & 7.4 \\
\hline 2002 & 865 & -1.7 & 1.2 & -18 & 18 & -14 & 13 & 12 & -15 & -0.7 & 0.3 & -5.8 & 5.1 \\
\hline 2003 & 882 & -1.4 & 1.0 & -19 & 18 & -14 & 14 & 12 & -16 & -0.6 & 0.4 & -4.9 & 5.0 \\
\hline 2004 & 838 & -1.5 & 0.9 & -19 & 18 & -14 & 14 & 13 & -13 & -0.8 & 0.6 & -7.2 & 6.4 \\
\hline 2005 & 733 & -2.1 & 1.6 & -19 & 17 & -14 & 13 & 10 & -11 & -0.7 & 0.5 & -9.9 & 6.9 \\
\hline Mean & 820 & -1.8 & 1.2 & -19 & 18 & -14 & 13 & 12 & -14 & -0.8 & 0.5 & -7.3 & 6.1 \\
\hline \multicolumn{14}{|c|}{ Total WF } \\
\hline 1996 & 955 & 4.7 & -3.1 & -26 & 29 & -20 & 22 & 20 & -24 & -1.1 & 0.5 & -4.1 & 4.1 \\
\hline 1997 & 1200 & 3.9 & -3.6 & -28 & 30 & -21 & 22 & 13 & -18 & -0.4 & 0.7 & -9.4 & 8.0 \\
\hline 1998 & 1001 & 4.2 & -2.8 & -26 & 29 & -20 & 22 & 16 & -17 & 0.2 & 0.0 & -5.6 & 4.8 \\
\hline 1999 & 1172 & 5.3 & -3.7 & -27 & 31 & -21 & 23 & 20 & -21 & -0.1 & 0.1 & -7.5 & 6.2 \\
\hline 2000 & 1172 & 3.7 & -3.1 & -27 & 28 & -20 & 21 & 23 & -24 & -0.4 & 0.5 & -8.6 & 6.8 \\
\hline 2001 & 1257 & 3.6 & -3.1 & -27 & 28 & -21 & 21 & 20 & -21 & -0.4 & 0.6 & -9.8 & 7.4 \\
\hline 2002 & 1160 & 4.7 & -3.7 & -27 & 29 & -20 & 22 & 15 & -17 & 1.2 & -0.5 & -5.8 & 5.1 \\
\hline 2003 & 1116 & 4.9 & -3.5 & -26 & 30 & -20 & 22 & 19 & -21 & -0.4 & 0.3 & -4.9 & 5.0 \\
\hline 2004 & 1098 & 4.4 & -3.3 & -26 & 29 & -20 & 22 & 22 & -20 & -0.4 & 0.4 & -7.2 & 6.4 \\
\hline 2005 & 1021 & 5.4 & -3.6 & -28 & 32 & -21 & 24 & 18 & -19 & -0.2 & 0.1 & -9.9 & 6.9 \\
\hline Mean & 1115 & 4.5 & -3.3 & -27 & 30 & -20 & 22 & 19 & -20 & -0.2 & 0.3 & -7.3 & 6.1 \\
\hline
\end{tabular}

\section{Conclusions and discussion}

This paper provides the first detailed study of the sensitivities and uncertainties in the estimation of green and blue water footprints of crop growing related to input variability and uncertainties at river-basin level. The result shows that at the scale of the Yellow River basin (1) WF is most sensitive to errors in $\mathrm{ET}_{0}$ and $K_{\mathrm{c}}$, followed by the crop planting date and PR, and less sensitive to changes of $S_{\mathrm{max}}, K_{\mathrm{y}}$, and $Y_{\mathrm{m}}$; (2) blue WF is more sensitive and has more uncertainty than green WF; (3) uncertainties in total (green + blue) WF as a result of climatic uncertainties are around $\pm 20 \%$ (at $95 \%$ confidence level) and dominated by effects from uncertainties in $\mathrm{ET}_{0}$; (4) uncertainties in total $\mathrm{WF}$ as a result of all uncertainties considered are on average $\pm 30 \%$ (at $95 \%$ confidence level); (5) the sensitivities and uncertainties in WF estimation, particularly in blue WF estimation, differ across crop types and vary from year to year.

An interesting finding was that the smaller the annual blue WF (consumptive use of irrigation water), the higher the sensitivity of the blue WF to variability in the input variables PR, $\mathrm{ET}_{0}$, and $K_{\mathrm{c}}$. Furthermore, delaying the crop planting date was found to potentially contribute to a decrease of the WF of spring or summer planted crops (maize, soybean, rice), 
Table 4. Values of $2 \times$ standard deviation for the probability distribution of the blue, green and total WF of maize, soybean, rice and wheat, expressed as \% of the mean value, from the Monte Carlo simulations.

\begin{tabular}{|c|c|c|c|c|c|c|c|c|c|c|}
\hline \multirow{2}{*}{ Crop } & \multirow{2}{*}{ Perturbed inputs } & \multicolumn{3}{|c|}{1996 (wet year) } & \multicolumn{3}{|c|}{2000 (dry year) } & \multicolumn{3}{|c|}{2005 (average year) } \\
\hline & & Blue WF & Green WF & Total WF & Blue WF & Green WF & Total WF & Blue WF & Green WF & Total WF \\
\hline \multirow{4}{*}{ Maize } & $P$ & 14 & 4 & 0.2 & 10 & 4 & 0.2 & 8 & 4 & 0 \\
\hline & $\mathrm{ET}_{0}$ & 48 & 12 & 20 & 38 & 12 & 20 & 36 & 12 & 18 \\
\hline & $P+\mathrm{ET}_{0}$ & 48 & 12 & 20 & 42 & 12 & 20 & 38 & 14 & 20 \\
\hline & $P+\mathrm{ET}_{0}+K_{\mathrm{c}}+D$ & 88 & 21 & 34 & 78 & 20 & 36 & 66 & 19 & 32 \\
\hline \multirow{4}{*}{ Soybean } & $P$ & 22 & 1.2 & 0.2 & 18 & 2 & 2 & 14 & 2 & 0.8 \\
\hline & $\mathrm{ET}_{0}$ & 56 & 16 & 18 & 50 & 14 & 16 & 40 & 14 & 16 \\
\hline & $P+\mathrm{ET}_{0}$ & 62 & 16 & 18 & 56 & 14 & 18 & 44 & 14 & 18 \\
\hline & $P+\mathrm{ET}_{0}+K_{\mathrm{c}}+D$ & 87 & 26 & 29 & 92 & 25 & 31 & 66 & 25 & 28 \\
\hline \multirow{4}{*}{ Rice } & $P$ & 10 & 6 & 0 & 8 & 6 & 0 & 7 & 6 & 0 \\
\hline & $\mathrm{ET}_{0}$ & 34 & 12 & 20 & 30 & 12 & 20 & 30 & 12 & 20 \\
\hline & $P+\mathrm{ET}_{0}$ & 34 & 12 & 20 & 32 & 12 & 20 & 32 & 13 & 20 \\
\hline & $P+\mathrm{ET}_{0}+K_{\mathrm{c}}+D$ & 70 & 18 & 31 & 66 & 21 & 32 & 61 & 19 & 29 \\
\hline \multirow{4}{*}{ Wheat } & $P$ & 14 & 2 & 0.4 & 14 & 2 & 0.4 & 16 & 2 & 0 \\
\hline & $\mathrm{ET}_{0}$ & 48 & 16 & 20 & 46 & 16 & 18 & 52 & 16 & 18 \\
\hline & $P+\mathrm{ET}_{0}$ & 52 & 16 & 20 & 48 & 16 & 18 & 54 & 16 & 18 \\
\hline & $P+\mathrm{ET}_{0}+K_{\mathrm{c}}+D$ & 85 & 24 & 26 & 83 & 24 & 31 & 88 & 22 & 30 \\
\hline
\end{tabular}

Optimizing the planting period for such crops could save irrigation water in agriculture, particularly for maize and rice. Although the conclusion closely matches the result from several experiments for maize carried out in some regions in northern China (Qin et al., 2012; Jin et al., 2012; Sun et al., 2007), such information should be confirmed by future field agronomic experiments.

The study confirmed that it is not enough to give a single figure of WF without providing an uncertainty range. A serious implication of the apparent uncertainties in Water Footprint Assessment is that it is difficult to establish trends in WF reduction over time, since the effects of reduction have to be measured against the background of natural variations and uncertainties.

The current study shows possible ways to assess the sensitivity and uncertainty in the water footprint of crops in relation to variability and errors in input variables and parameters. Not only can the outcomes of this study be used as a reference in future sensitivity and uncertainty studies on WF, but the results also provide a first rough insight in the possible consequences of changes in climatic variables like precipitation and reference evapotranspiration on the water footprint of crops. However, the study does not provide the complete picture of sensitivities and uncertainties in Water Footprint Assessment. Firstly, the study is limited to the assessment of the effects from only a part of all input variables and parameters; uncertainties in other parameters were not considered, such as the uncertainties around volumes and timing of irrigation, parameters affecting runoff and deep percolation. Secondly, there are several models available for estimating the WF of crops. Our result is only valid for the model used, which is based on a simple soil water balance (Allen et al., 1998; Mekonnen and Hoekstra, 2010) and which considers water as the main factor in the yield estimation (Eq. 6). Thirdly, the quantification of uncertainties in the input variables considered is an area full of uncertainties and assumptions itself. Furthermore, the uncertainties in water footprint estimation are scale dependent and decline with a growing extent of the considered study region. Our study is carried out for the aggregated crop water footprint estimation for the whole basin scale. The result should be interpreted with caution at a higher resolution. Besides, the uncertainty range of an input variable, especially for climatic inputs, is location specific. Thus the level of input uncertainties will be different in different places, resulting in a different level of uncertainties in crop water footprints. Therefore, the current result is highly valuable for the region of the YRB and should be referenced with caution at other regions.

Therefore, in order to build up a more detailed and complete picture of sensitivities and uncertainties in Water Footprint Assessment, a variety of efforts needs to be made in the future. In particular, we will need to improve the estimation of input uncertainties, include uncertainties from other input variables and parameters, and assess the impact of using different models on WF outcomes. Finally, uncertainty studies will need to be extended towards other crops and other water using sectors, to other regions and at different spatial and temporal scales. 
Acknowledgements. The authors would like to thank reviewer Tuomas J. Mattila, an anonymous reviewer and editor for valuable comments and suggestions. L. Zhuo is grateful for the scholarship she received from the China Scholarship Council (CSC), No. 2011630181.

Edited by: G. H. de Rooij

\section{References}

Ahn, H.: Sensitivity for correlated input variables and propagated errors in evapotranspiration estimates from a humid region, Water Resour. Res., 32, 2507-2516, 1996.

Aldaya, M. M. and Llamas, M. R.: Water footprint analysis for the Guadiana river basin, Value of Water research Report Series No. 35, UNESCO-IHE, Delft, the Netherlands, 2008.

Allen, R. G., Pereira, L. S., Raes, D., and Smith, M.: Crop evapotranspiration: guidelines for computing crop water requirements, FAO Drainage and Irrigation Paper 56, Food and Agriculture Organization, Rome, Italy, 1998.

Batjes, N. H.: ISRIC-WISE global data set of derived soil properties on a 5 by 5 arc-minutes grid (version 1.2), Report 2012/01, available at: www.isric.org, ISRIC - World Soil Information, Wageningen, the Netherlands, 2012.

Bocchiola, D., Nana, E., and Soncini, A.: Impact of climate change scenarios on crop yield and water footprint of maize in the Po valley of Italy, Agr. Water Manage., 116, 50-61, 2013.

Bulsink, F., Hoekstra, A. Y., and Booij, M. J.: The water footprint of Indonesian provinces related to the consumption of crop products, Hydrol. Earth Syst. Sci., 14, 119-128, doi:10.5194/hess-14119-2010, 2010.

Cai, X. M., Yang, Y.-C. E., Ringler, C., Zhao, J. S., and You, L. Z.: Agricultural water productivity assessment for the Yellow River Basin, Agr. Water Manage., 98, 1297-1306, 2011.

Chapagain, A. K. and Hoekstra, A. Y.: Water footprints of nations, Value of Water Research Report Series No. 16, UNESCO-IHE, Delft, the Netherlands, 2004.

Chen, Y., Guo, G., Wang, G., Kang, S., Luo, H., and Zhang, D.: Main crop water requirement and irrigation of China, Hydraulic and Electric Press, Beijing, China, 1995.

CMA: SURF_CLI_CHN_MUL_MON_CES v3.0, China Meteorological Data Sharing Service System, Chinese Meteorological Administration, available at: http://cdc.cma.gov.cn (last access: November 2011), 2008.

CMWR: China Water Resources Bulletin 2009, China Ministry of Water Resources, available at: www.mwr.gov.cn, last access: October 2010.

Doorenbos, J. and Kassam, A. H.: Yield response to water, FAO Drainage and Irrigation Paper 33, FAO, Rome, Italy, 1979.

Droogers, P. and Allen, R. G.: Estimating reference evapotranspiration under inaccurate data conditions, Irrig. Drain., 16, 33-45, 2002.

Estévez, J., Gavilán, P., and Berengena, J.: Sensitivity analysis of a Penman-Monteith type equation to estimate reference evapotranspiration in southern Spain, Hydrol. Process., 23, 3342-3353, 2009.

Falkenmark, M. and Widstrand, C.: Population and water resources: a delicate balance. Population Bulletin, Population Reference Bureau, Washington, D.C., USA, 1992.
Fekete, B. M., Vörösmarty, C. J., Roads, J. O., and Willmott, C. J.: Uncertainties in precipitation and their impacts on runoff estimates, J. Climate, 17, 294-304, 2004.

Feng, K. S., Siu, Y. L., Guan, D., and Hubacek, K.: Assessing regional virtual water flows and water footprints in the Yellow River Basin, China: A consumption based approach, Appl. Geogr., 32, 691-701, 2012.

Galli, A., Wiedmann, T., Ercin, E., Knoblauch, D., Ewing, B., and Giljum, S.: Integrating ecological, carbon and water footprint into a "footprint family" of indicators: Definition and role in tracking human pressure on the planet, Ecol. Indic., 16, 100-112, 2012.

Ge, L., Xie, G., Zhang, C., Li, S., Qi, Y., Cao, S., and He, T.: An evaluation of China's water footprint, Water Resour. Manage., 25, 2633-2647, 2011.

Goyal, R. K.: Sensitivity of evapotranspiration to global warming: a case study of arid zone of Rajasthan (India), Agr. Water Manage., 69, 1-11, 2004.

Guieysse, B., Béchet, Q., and Shilton, A.: Variability and uncertainty in water demand and water footprint assessments of fresh algae cultivation based on case studies from five climatic regions, Bioresource Technol. 128, 317-323, 2013.

Hamby, D. M.: A review of techniques for parameter sensitivity analysis of environmental models, Environ. Monit. Assess., 32, 135-154, 1994.

Harris, I., Jones, P. D., Osborn, T. J., and Lister, D. H.: Updated high-resolution grids of monthly climatic observations - the CRU TS3.10 Dataset, Int. J. Climatol., 34, 623-642, doi:10.1002/joc.3711, 2014.

Hoekstra, A. Y. (Ed.): Virtual water trade, in: Proceedings of the International Expert Meeting on Virtual Water Trade, IHE Delft, the Netherlands, 12-13 December 2002, Value of Water Research Report Series No. 12, UNESCO-IHE, Delft, the Netherlands, 2003.

Hoekstra, A. Y. and Chapagain, A. K.: Water footprints of nations: water use by people as a function of their consumption pattern, Water Resour. Manage., 21, 35-48, 2007a.

Hoekstra, A. Y. and Chapagain, A. K.: The water footprints of Morocco and the Netherlands: Global water use as a result of domestic consumption of agricultural commodities, Ecol. Econ., 64, 143-151, 2007b.

Hoekstra, A. Y. and Mekonnen, M. M.: The water footprint of humanity, P. Natl. Acad. Sci. USA, 109, 3232-3237, 2012.

Hoekstra, A. Y., Chapagain, A. K., Aldaya, M. M., and Mekonnen, M. M.: The water footprint assessment manual: Setting the global standard, Earthscan, London, UK, 2011.

Hoekstra, A. Y., Mekonnen, M. M., Chapagain, A. K., Mathews, R. E., and Richter, B. D.: Global monthly water scarcity: Blue water footprints versus blue water availability, PLoS ONE, 7, e32688, doi:10.1371/journal.pone.0032688, 2012.

Jagtap, S. S. and Jones, J. W.: Stability of crop coefficients under different climate and irrigation management practices, Irrigation Sci., 10, 231-244, 1989.

Jensen, M. E., Burman, R. D., and Allen, R. G. (Eds.): Evaporation and irrigation water requirements, ASCE Manuals and Reports on Engineering Practices No. 70, American Society of Civil Engineers, New York, USA, 1990.

Jin, L., Cui, H., Li, B., Zhang, J., Dong, S., and Liu, P.: Effects of integrated agronomic management practices on yield and nitro- 
gen efficiency of summer maize in North China, FIELD CROP RES, 134, 30-35, 2012.

Kampman, D. A., Hoekstra, A. Y., and Krol, M. S.: The water footprint of India, Value of Water Research Report Series No. 32, UNESCO-IHE, Delft, the Netherlands, 2008.

Lehner, B., Verdin, K., and Jarvis, A.: New global hydrography derived from space borne elevation data, Eos, 89, 93-94, 2008.

Liu, J. and Savenije, H. H. G.: Food consumption patterns and their effect on water requirement in China, Hydrol. Earth Syst. Sci., 12, 887-898, doi:10.5194/hess-12-887-2008, 2008.

Liu, Q., Yang, Z., Cui, B., and Sun, S.: The temporal trends of reference evapotranspiration and its sensitivity to key meteorological variables in the Yellow River Basin, China, Hydrol. Process., 24, 2171-2181, 2010.

Ma, J., Hoekstra, A. Y., Wang, H., Chapagain, A. K., and Wang, D.: Virtual versus real water transfers within China, Philos. T. Roy. Soc. B, 361, 835-842, 2006.

MAPRC: Sixty years agricultural statistics of New China, Ministry of Agriculture of the People's Republic of China, China Agriculture Press, Beijing, China, 2009.

Mattila, T., Leskinen, P., Soimakallio, S., and Sironen, S.: Uncertainty in environmentally conscious decision making: beer or wine?, Int. J. Life Cycle Ass., 17, 696-705, 2012.

McMaster, G. S. and Wilhelm, W. W.: Growing degree days: one equation, two interpretations, Agr. Forest. Meteorol., 87, 297300, 1997.

Mekonnen, M. M. and Hoekstra, A. Y.: A global and high-resolution assessment of the green, blue and grey water footprint of wheat, Hydrol. Earth Syst. Sci., 14, 1259-1276, doi:10.5194/hess-141259-2010, 2010.

Mekonnen, M. M. and Hoekstra, A. Y.: The green, blue and grey water footprint of crops and derived crop products, Hydrol. Earth Syst. Sci., 15, 1577-1600, doi:10.5194/hess-15-15772011, 2011.

Meyer, S. J., Hubbard, K. G., and Wilhite, D. A.: Estimating potential evapotranspiration: the effect of random and systematic errors, Agr. Forest. Meteorol., 46, 285-296, 1989.

Meyer, V. R.: Measurement uncertainty, J. Chromatogr. A, 1158, 15-24, 2007.

NBSC: China agricultural statistical yearbook assembly 19492004, National Bureau of Statistics of China, China Statistics Press, Beijing, China, 2006.

NBSC: China Rural statistical yearbook 2006, National Bureau of Statistics of China, China Statistics Press, Beijing, China, 2007.

Oki, T. and Kanae, S.: Global hydrological cycles and world water resources, Science, 313, 1068-1072, 2006.

Parker, R. W. R. and Tyedmers, P. H.: Uncertainty and natural variability in the ecological footprint of fisheries: A case study of reduction fisheries for meal and oil, Ecol. Indic., 16, 76-83, 2012.

Phillips, D. L. and Marks, D. G.: Spatial uncertainty analysis: propagation of interpolation errors in spatially distributed models, Ecol. Model., 91, 213-229, 1996.

Portmann, F. T., Siebert, S., and Döll, P.: MIRCA2000 - Global monthly irrigated and rain-fed crop areas around the year 2000: A new high-resolution data set for agricultural and hydrological modeling, Global Biogeochem. Cy., 24, GB1011, doi:10.1029/2008GB003435, 2010.
Qin, L. J., Jin, Y. H., and Duan, P. L.: Impact of different planting dates on green water footprint of maize in western Jilin Province, Acta Ecol. Sin., 32, 7375-7382, 2012.

Raes, D., Steduto, P., Hisiao, T. C., and Fereres, E.: Reference Manual, Annex I - AquaCrop, Version 4.0, FAO, Land and Water Division, Rome, Italy, 2012.

Reynolds, C. A., Yitayew, M., Slack, D. C., Hutchinson, C. F., Huete, A., and Petersen, M. S.: Estimating crop yields and production by integrating the FAO Crop Specific Water Balance model with real-time satellite data and ground-based ancillary data, Int. J. Remote Sens., 21, 3487-3508, 2000.

Ringler, C., Cai, X. M., Wang, J. X., Ahmed, A., Xue, Y. P., Xu, Z. X., Yang, E. T., Zhao, J. S., Zhu, T. J., Cheng, L., Fu, Y. F., Fu, X. F., Gu, X. W. and You, L. Z.: Yellow River basin: living with scarcity, Water Int., 35, 681-701, 2010.

Röös, E., Sundberg, C., and Hansson, P. A.: Uncertainties in the carbon footprint of food products: a case study on table potatoes, Int. J. Life Cycle Ass., 15, 478-488, 2010.

Röös, E., Sundberg, C., and Hansson, P. A.: Uncertainties in the carbon footprint of refined wheat products: a case study on Swedish pasta, Int. J. Life Cycle Ass., 16, 338-350, 2011.

Schuol, J. and Abbaspour, K. C.: Using monthly weather statistics to generate daily data in a SWAT model application to West Africa, Ecol. Model., 201, 301-311, 2007.

Siebert, S. and Döll, P.: Quantifying blue and green virtual water contents in global crop production as well as potential production losses without irrigation, J. Hydrol., 384, 198-217, 2010.

Sun, H., Zhang, X., Chen, S., Pei, D., and Liu, C.: Effects of harvest and sowing time on the performance of the rotation of winter wheat-summer maize in the North China Plain, IND CROP PROD, 25, 239-247, 2007.

Sun, S. K., Wu, P. T., Wang, Y. B., and Zhao, X. N.: Temporal variability of water footprint for maize production: The case of Beijing from 1978 to 2008, Water Resour. Manage., 27, 2447-2463, 2013.

Sun, X. Y., Newham, L. T. H., Croke, B. F. W., and Norton, J. P.: Three complementary methods for sensitivity analysis of a water quality model, Environ. Model. Softw., 37, 19-29, 2012.

Thomas, A.: Development and properties of 0.25-degree gridded evapotranspiration data fields of China for hydrological studies, J. Hydrol., 358, 145-158, 2008.

Troutman, B. M.: Errors and Parameter Estimation in PrecipitationRunoff Modeling: 1. Theory, Water Resour. Res., 21, 1195-1213, 1985.

Vörösmarty, C. J., Green, P., Salisbury, J., and Lammers, R. B.: Global water resources: Vulnerability from climate change and population growth, Science, 289, 284-288, 2000.

Walker, W. E., Harremoës, P., Rotmans, J., Van der Sluis, J. P., Van Asselt, M. B. A., Janssen, P., and Krayer von Krauss, M. P.: Defining uncertainty: a conceptual basis for uncertainty management in model-based decision support, Integrat. Ass., 4, 5-17, 2003.

Xu, C. Y., Tunemar, L., Chen, Y. Q. D., and Singh, V. P.: Evaluation of seasonal and spatial variations of lumped water balance model sensitivity to precipitation data errors, J. Hydrol., 324, 80-93, $2006 a$.

Xu, C. Y., Gong, L. B., Jiang, T., Chen, D. L., and Singh, V. P.: Analysis of spatial distribution and temporal trend of reference 
evapotranspiration and pan evaporation in Changjiang (Yangtze River) catchment, J. Hydrol., 327, 81-93, 2006 b.

YRCC: Yellow River water resource bulletin 2010, available at: www.yellowriver.gov.cn, Yellow River Conservancy Commission, Zhengzhou, China, 2011.
Zeng, Z., Liu, J., Koeneman, P. H., Zarate, E., and Hoekstra, A. Y.: Assessing water footprint at river basin level: a case study for the Heihe River Basin in northwest China, Hydrol. Earth Syst. Sci., 16, 2771-2781, doi:10.5194/hess-16-2771-2012, 2012.

Zhao, T. B. and Fu, C. B.: Comparison of products from ERA-40, NCEP-2, and CRU with station data for summer precipitation over China, Adv. Atmos. Sci., 23, 593-604, 2006. 